Bacterial bother
$\begin{aligned} & \text { Us researchers } \\ & \text { wrestle with legality } \\ & \text { of pathogen storage } \\ & p 4\end{aligned}$ $\begin{aligned} & \text { All at sea } \\ & \text { Budget cuts leave } \\ & \text { ocean institute } \\ & \text { fearful for the future } \\ & p 5\end{aligned}$

\title{
Petition calls for clampdown on absentee Chinese researchers
}

\section{David Cyranoski}

A group of Chinese scientists is calling for a crackdown on colleagues who, they allege, receive the most sought-after grants but fail to devote enough time to research within China.

China has watched many of its best young researchers head off to the United States and elsewhere over the past decade, and is now trying lure hundreds of them back, often on generous terms. But as the petition shows, the effort is creating tensions in China's rapidly expanding scientific community.

Some grantees are using the money to set up laboratories in China but then spend most of their time abroad, according to a letter to agency directors signed by 26 researchers from the Chinese Academy of Sciences (CAS) and various universities and research institutions. The letter says that the practice defies the terms of the grants, which require recipients to spend six or nine months in China.

"I am strongly against those who cheat on the working time required by positions or funding in China," says Zhuan Zhou of the CAS Institute of Neuroscience in Shanghai, who signed and helped to circulate the letter.

The petition was sent to the heads of the CAS, the science and technology ministry, the education ministry and the National Nat-

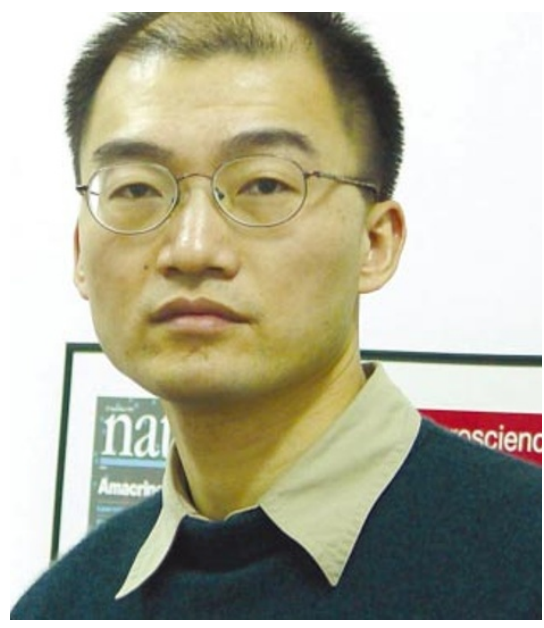

Fair play: Shigang He wants to see grantees carry out more of their research in China.

ural Science Foundation of China (NNSFC) on 19 December.

The letter's author, Shigang He, also of the Institute of Neuroscience, claims that at least a dozen people in the life sciences alone are wasting China's resources. These researchers do most of their important work overseas, leaving largely unsupervised labs in China where graduate students or assistant researchers do not know how to use the equipment, he says. "The money gets taken away from people who are really qualified and is given to people who are not," He says.

Some heads of institutes within the CAS are already taking measures in response to the researchers' concerns. Yongbiao Xue, associate director of the CAS Institute of Genetics and Developmental Biology in Beijing, says that researchers who fail to meet the time requirements at his institution risk losing their lab.

The issue is of particular concern because grants from several government sources often end up in the same hands, as success with one grant application often paves the way to success with others, says He.

The funding agencies should monitor the use of the grants more closely by checking passports, He suggests, or requiring a written notice from the researcher's previous overseas institution stating it is aware that the researcher is taking on another full-time post. "The rule is there," he says. "They just have to enforce it."

But Chen Jia'er, president of the NNSFC, says that the problem is not so severe, noting that its grants involve strict evaluations and progress reports. But he acknowledges that "the issue raised is something we should pay more attention to".

\section{Human cloning claim sparks fear of Senate backlash}

\section{Colin Macilwain, Washington}

Concern is mounting among US biologists that unconfirmed reports of the birth of cloned babies could force through legislation that will outlaw any cloning of human embryos, even for research purposes.

Senator Sam Brownback (Republican, Kansas) is set to reintroduce legislation in the next few weeks that would enact such a ban. In the past, Brownback has been unable to garner the 60 Senate votes that are needed to pass his legislation, in the face of trenchant opposition from researchers.

On 27 December, however, Clonaid, a company controlled by the Raelian sect, a religious group that believes in extraterrestrials, told a disbelieving world that a cloned baby had been born at an undisclosed location. The claim - for which no evidence has yet been presented - is likely to be the first of several over the next few weeks from various doctors around the world.

Whether genuine or not, the claim may serve to build support for Brownback's legislation. Importantly, his proposal has the backing of new Senate Republican leader Bill Frist (Tennessee), a heart surgeon who normally supports biomedical research.
Frist was elected on 23 December after Senator Trent Lott (Republican, Mississippi) was forced to resign.

Brownback's bill is also backed by President George Bush, and is similar to a measure that has already been passed by the House of Representatives. Besides making reproductive cloning illegal, it would also outlaw 'therapeutic cloning' of embryos to produce stem cells for research purposes. A rival measure, that would allow therapeutic cloning while banning the cloning of babies, has the support of scientific organizations but lacks the votes to be passed in either the House or the Senate, observers say. 